\title{
Teaching Skills Development Using Lesson Study-based Instruction in Writing Classes
}

\author{
Dewa Ayu Ari Wiryadi Joni \\ Universitas Mahasaraswati Denpasar, Denpasar
}

\section{Abstract}

This research was resulted from the Lesson Study for Learning Community Program held in Faculty of Teacher Training and Education Universitas Mahasaraswati Denpasar. This study was a qualitative study which aimed at analyzing the teaching skills development of writing lecturers using lesson study in teaching writing skill to the students of ELSP in academic year 2016/2017. The teaching skills development included practical skills in designing lesson plans, deciding learning materials, teaching media, students' worksheets, scoring rubric and post-tests, motivating students, managing the classroom, communicating ideas, assessing learning outcomes and reviewing information. This study was done in 3 cycles with 3 parallel sessions; plan, do and see. The research

Corresponding Author: Dewa Ayu Ari Wiryadi Joni wiryadijoni@ymail.com

Received: 23 January 2019 Accepted: 26 February 2019 Published: 17 March 2019

Publishing services provided by Knowledge E

(c) Dewa Ayu Ari Wiryadi Joni. This article is distributed under the terms of the Creative Commons Attribution License, which permits unrestricted use and redistribution provided that the original author and source are credited.

Selection and Peer-review under the responsibility of the International Seminar on Language, Education, and Culture Conference Committee. instruments used were observational sheets during each session and questionnaires. It was found that the teaching skills of lecturers of writing subject were developed. They could arrange lesson plans based on the chapter design and lesson design; chose interesting learning materials and teaching media; give suitable students' worksheets and post-tests using scoring rubric to give opportunities for the students to think creatively and critically; implement an appropriate teaching technique to give chances for the students to work collaboratively and communicatively; manage classroom activities which were conducive to help the students get engaged during the instruction. This had caused the students more motivated in following the lessons and training their writing skill. This study provided empirical evidences about lesson study based instruction to evaluate educators' teaching skills development in teaching writing.

Keywords: teaching skills development, writing skill, lesson study.

\section{Introduction}

Based on SoTL found in Uppsala University's Rules and Procedures (2010), pedagogical competency is considered to be the educational and teaching qualifications. As a language instructor, it is compulsory to have a definite pedagogical competency. When talking about this pedagogical competency in higher education, the teaching skills have become the core consideration. The teaching qualification found in Faculty of Teacher Training and Education (hereafter FTTE) Unmas Denpasar suggests that every lecturer must have a mutual qualification with the study program where they teach. As cited in 
the book of Vision and Mission of English Language Study Program (hereafter ELSP) in FTTE Unmas Denpasar (2010), the ELSP has views to become a study program that has qualification in academic achievement and local wisdoms. To meet these requirements, the officials oblige the ELSP lecturers to have teaching skills qualification that nurture the students' achievement both in educational and cultural accomplishments. The graduates are expected not only to become teachers that are qualified in knowledge readiness but also in preserving local wisdoms. Hence, the teaching skills of the language educators in ELSP are crucial to be maintained and well-sustained considering the important remarks of the ELSP Vision and Mission.

Many teachers are revered for their teaching skills by both their students and colleagues. The teaching skills refer to the practical experiences and the ability to contribute to students learning by leading, organizing, planning, implementing, examining, developing and evaluating different types of teaching and education levels and producing teaching materials (Ryegard, Olsson and Apelgreen, 2010). These teaching skills determine the students' learning experiences during instructions. Supporting this point of view, Slavin (2009) proposes tasks involving teacher teaching in and out of classroom settings, which integrate the practical ability of designing and executing lesson plans along with motivating students, managing the classroom, assessing knowledge, communicating ideas, considering students' characteristics, assessing learning outcomes and reviewing information, that must be existed at each level of education. As these teaching skills occur during instruction, the effective teaching which is all teachers expect for may be done and gives positive impacts for students.

In addition, in the point of view of the students' learning benefits, Susilo (2017) mentions that the life skills that are demanded to possess by the students in the $21^{\text {st }}$ century are the skills of being communicative, critical, creative and able to work collaboratively. These life skills are encompassed in the teaching of language skills either receptive skills (reading and listening) or productive skills (speaking and writing) in any level of education. Regarding of the teaching of one of the productive skills, which is writing skill, the language instructors are responsible to have their students train their writing skill while at the same time undergoing these four life skills in and out of classroom settings. This is a challenge for language instructors in ELSP FTTE Unmas Denpasar. As the teaching skills owned by the ELSP instructors would give direct impacts to the quality of the instruction, which automatically affect students' learning experiences, the instructors are provoked to conduct processes of shaping effective teaching which can sustain and foster the instructors' teaching skills as well as promote students' $21^{\text {st }}$ century life skills. 
Seeing that effective teaching, which means that instructors must acquire critical thinking and problem-solving skills, have self-knowledge and self-regulation, understand knowledge of students and their learning and possess teaching and communication skills (Slavin, 2009), can be thoroughly taught and learnt, the ELSP language educators are interested in having a practical fortification using Lesson Study Program. Lesson Study can be well-customized with various methods. It is liable to have teachers share experiences and evaluate each other with the intention of upgrading teaching-learning processes (Sudrajat in Sandi, 2010). Moreover, lesson study lets the teachers help and encourage each other in doing Plan, Do and See. The collaborative work of lesson study has advantages that not only can the instructors enrich their knowledge and comprehend their pedagogical responsibility but also they can observe as well as understand how their students study (Murata and Takahasi, 2002).

\section{Research Methods}

This research was a qualitative study. In carrying out this study, the researcher employed the steps of Lesson Study such as Plan, Do and See in 3 cycles. The subjects of the study were the writing lecturers (hereafter models) of semester IIIA and IIA students of ELSP FTTE Unmas Denpasar in academic year 2016/2017. The research instruments used were observational sheets during each session and questionnaire for the students in the end of cycle III. The steps of lesson study could be seen as follows:

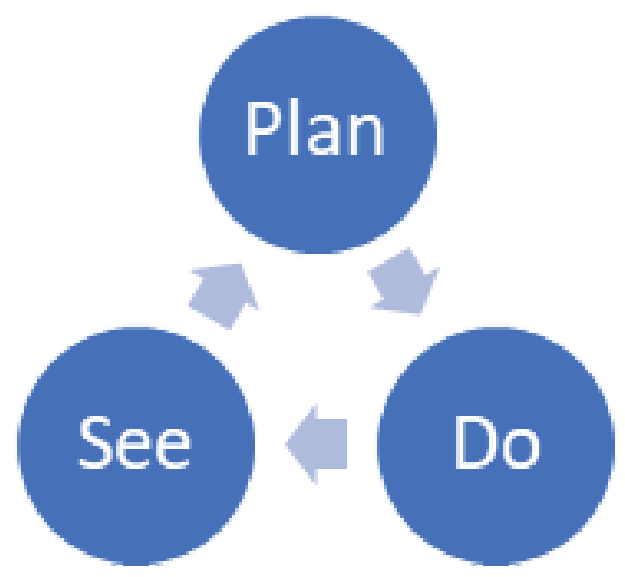

Figure 1: The Steps of Lesson Study.

The monitoring guide during Plan sessions consisted of 16 items about the models' preparation before doing Do and See sessions which mainly focused on the lesson plan, learning materials, teaching media and evaluation. There were two sheets used for Do sessions such as monitoring guide of Do session which featured 11 items about 
the models' performances during teaching-learning processes; and classroom observational sheet of Do session which included 7 items about the students' learning activities. The observational sheet for See sessions included 14 items about the reflection of Do sessions. The questionnaire given consisted of 4 items which remarked the students' opinion about the teaching-learning processes.

After corroborating the research instruments, the researcher who was in charge as one of the observers aided the models to prepare teaching instruments needed for Do and See sessions, such as chapter design, lesson design, lesson plans, teaching media, scoring rubric, students' worksheets and post-tests. The observers gave valuable opinions and suggestions to alter those teaching instruments used. After validating them, the models then proceeded to the completion of Do session. In this session, the models, being observed by four observers, implemented the technique selected according to the lesson plans and lesson design prepared to the students of IIIA and IIA of ELSP FTTE Unmas Denpasar in academic year 2016/2017 in 100 minutes.

Following the Do session, the models along with four observers conducted See session. At this point, the observers identified the strengths and weaknesses of the models, and gave their opinions and evaluation regarding of the implementation of Do session. They reported the details viewing from how the models conducted the teaching processes and how active the students were.

By learning the strengths and weaknesses from the previous cycle, the models and the observers revised the planning to perfect the teaching-learning processes for next cycles.

\section{Findings and Discussion}

By applying lesson study based instruction in teaching writing skill to the students of semester IIIA and IIA of ELSP FTTE Unmas Denpasar in academic year 2016/2017, it could be seen that the models' teaching skills were developed in each session. For further explanation, it can be elaborated as follows:

\subsection{Cycle I}

In cycle I, during Plan session, the researcher who acted as one of the observers discussed and monitored the models' preparation before doing Do session. It was found that there were some difficulties faced by the models, such as designing the chapter 
design and lesson design, preparing materials and teaching media, deciding assessment technique and choosing appropriate teaching technique used in writing classes. The models along with the observers then created chapter design and lesson design together. Afterward, the models arranged lesson plans. During monitoring Plan session, it was noticed several points; those were (1) learning objectives were not included, (2) teaching media was less necessary, (3) the time allotment in Do session was not the fundamental part, (4) assessment technique; in this case it was the use of scoring rubric; was not used. Along with the discussion in Plan session, the observers also suggested the models prepare students' worksheet in teaching paragraph writing and argumentative essay, which was closely related to students' lives. The materials were delivered in writing classes using problem-solving learning method combined with group discussion.

After getting the teaching instruments ready, the models proceeded to conduct the Do session. The models taught paragraph writing to semester IIA students with the material about describing person; and argumentative essay writing to semester IIIA students with the material about making thesis statement. The observers monitored the models' teaching skill performances using monitoring guide as well as observed students' learning activities using observational sheet. The models executed the arranged lesson plan and performed individually without interruption of the observers. In this session, based on the monitoring guide used, the researcher noted that the models had demonstrated adequate teaching skill performances. It could be seen from the notes and comments given by each observer and the students' participation during instruction. The observers noted that the model in teaching paragraph writing to semester IIA students showed that she had mastered the content of her writing subject about characteristics of a good descriptive paragraph which focused on writing main idea, supporting sentences and conclusion; and making a unified and coherent descriptive paragraph about person using correct generic structures and transition signals. She also adapted the lesson plans according to the class situation. In addition, she could give answers to students' questions. She also managed the activities accordingly with firm discipline. However, there were quite a few flaws found; those were (1) she did not inform the learning objective to the students even though it was mentioned in lesson design, (2) she gave less arousing apprehension, (3) she did not use teaching media and scoring rubric, (4) she spent more than the time allotment given for every meeting, and (5) there were 2 groups having difficulties in group discussion.

Simultaneously, the data taken using observational sheet showed that the students' learning experience was less meaningful. It could be confirmed from the elaboration recorded by the observers that mainly talked whether the students had actually learned 
or not. It was noted that around 8 out of 35 students did not learn the material well and understand what to do. When working and discussing in groups, these students tended to keep silent or waited for other group members to finish the group job. Instead of working together to solve the problem given, they preferred to wait and agree on whatever the group had decided. These were caused by homogenous groups which were formed not according to their mixed level of ability. They also chose to speak in Indonesian rather than in English for they were less proficient in English. When making a group writing product, most of students were still confused of what and how to write for they were unable to come with a good idea of how to start writing and how to continue their friends' idea to make the paragraph coherent and unified.

In addition, they might also be affected by the observers roaming around in classroom even though the observers did not make any direct contact with them. The observers' presences might make them feel intimidated and uneasy so that was likely to cause them less concentrate on the lesson. Moreover, the use of less interesting power point presentation affected their motivation to learn. It was better if the model had used pictures of someone attractive to provoke their focus to learn as pictures allowed them to imagine vividly.

Likewise, the model who taught argumentative essay writing to semester IIIA students performed the agreed lesson plan without changing it to the classroom situation. She also faced some obstacles when carrying out Do session. Based on monitoring guide of Do session, it was seen that she (1) gave less interesting apprehension to start the lesson, (2) did not thoroughly talk about learning objectives as been stated in lesson design, (3) did not use scoring rubric, (4) spent more than time allotment given, and (5) there were 7 out of 18 pairs having troubles during group discussion session. Additionally, it was proven that she had understood her writing subject argumentative essay writing about making thesis statement well so that she could give answers to students' questions and misunderstanding did not take place.

Based on the observational sheet used, it was found that almost all of the students learned the material. When working in pairs, most of them had interacted with their pairs but it was not quite effective. There were 10 out of 36 students who seemed unable to focus as they had not tuned in yet. These students preferred to chat about things unrelated with the material with their pairs or play with their smart phones. Some of them looked blank as the model explained the material. As the instruction given by the model, these students did not quite catch what to do and faced difficulties to follow the lesson. During discussion session, they spoke most in mixed-languages of Indonesian and English for they lacked English proficiency. The model should have given more 
interesting apprehension with amusing topics and notify clear learning objectives so that would grab their attention and give them motivation to study (Hoover, 1966).

After the Do session was finished, it was continued to have See session. Based on the monitoring guide used, the models and the observers reflected of what had happened during Do session. At this point, the models shared what they had experiences and the observers reported what they had observed. The See session was done in the form of group discussion in which there were a moderator, a note-taker, the models and the observers in one room. It was found that the models were nervous, starting when opening the class, in the middle of it and closing it. They said that it was their first time to be monitored and observed by other teachers and be recorded in a camera. This had caused them anxious of their observation results. As the result showed that there were some students sitting at the back who could not concentrate well. They looked sleepy and blank. This was caused by the lack of the models' attention that only focused on those sitting in front and middle rows, and the less stimulating apprehension which only showed more theories than the examples. In addition, the students' worksheets used were simple but there were some spelling and punctuation mistakes found. As simple and easy the worksheet was as less enthusiastic students would be. Instead of practicing their writing skill to make a meaningful paragraph, they opted to make the simple one as instructed in the worksheet. Through this lesson study program, the models felt that they were benefited for they could share and know what their strengths and weaknesses in teaching so that they could minimize the weaknesses and keep the strengths to plan for the next teaching skill performances as the foremost strength of cyclical process of lesson study program is to allow the instructors to mirror on their strengths, weaknesses and areas for development and restructure former experience with the intention to perfect practices (Myers, 2012).

\subsection{Cycle II}

Cycle II was the continuation of the preceding material in cycle I. Paragraph writing in semester IIA class was about describing thing and argumentative essay writing in semester IIIA class was about structure of argumentative essay. The steps of cycle II were the same as the previous cycle, consisting of 3 sessions; Plan, Do and See.

During Plan session, as suggested by the observers, the models made some revisions on the lesson designs and the lesson plans. They had changed the topics along with their materials which were more authentic, used analytical scoring rubric, prepared 
teaching media in the form of pictures, used powerful power point presentation complemented with boxes and bullets and more detailed examples, and arranged more challenging students' worksheets which were closely related to students' daily lives.

Throughout Do session, the models used the same teaching syntax as in cycle I; but the models congregated the students' attention intensely first by giving apprehension using pictures and humorous questions. By having the students feel joyful and relaxed; they could picture the later on material vividly. As mentioned by Brown (1994), laughing with the students and having them share fears in small groups would foster intrinsic motivation among students in classroom. The models also explained the learning objectives and experiences they would retain. In delivering materials, the models used teaching media such as colorful pictures and handouts to help the students to understand better. The stimulus triggered by such situation helped the students to decide and comprehend what learning experiences to be expected; they could think critically and use verbal communication to identify expectations for producing creative products (Herrel and Jordan, 2004). Furthermore, the models had changed some parts of the lesson plans according to the class situation. The models had provided a less-structured learning atmosphere in which it could stimulate the students to delve into what they considered important and drew out a collaborative and creative component which led the students to see each other points of view and made decisions (Myers, 2012). They divided the group heterogeneously according to students' diverse ability to let them open themselves and discuss the groups' products together as the groups would give them a positive pressure to finish the tasks (Hoover, 1966).. These groups' writing products were displayed in front of the class to discuss together and give recognition. Approaching the end of the lesson, the models gave individual work which was then scored using analytical scoring rubric; thus, the students knew their marks that could augment their motivation in learning and prepare themselves for the next instruction (Hamalik, 2008).

In semester IIA class, through observation, it was found that the model taught paragraph writing past the time allotment given for she gave a more challenging worksheet compared to cycle I and post-test; thus the students needed more time to finish them. There were 2 groups facing difficulties during group discussion session. They took longer time to continue the other members' idea to make a coherent writing for they were seen unsure of what they had written was correct or not and anxious of what other members would say about their parts. They seemed to realize that they were not competent enough like the other members and shy to ask for assistance. Hence, they were likely to check in dictionary and revise their own writing parts by themselves; afterward they managed to get confidence to have discussion with other members to settle on which 
ideas should be included in group product or not. As the model demanded the students to use English during group discussion, these students felt burdened. They conveyed less eloquent argumentation to maintain their ideas. Additionally, there were 4 out of 35 students who could not learn the material well because they looked blank and dozed off often. They did not comprehend what the model had instructed and felt safer to ask their friends rather than the model as they were afraid to ask using English. As the individual post test was given, they looked troubled and constructed a less coherent descriptive paragraph. The model should have verged on these students and helped them when necessary by giving clues or telling appropriate diction; hence, code-switching might have not occurred frequently and their writing had become more interesting to read.

Likewise, in semester IIIA class, the model observed showed a great effort in managing students' learning activities even though she exceeded the time allotment given. As she taught quite uneasy material which required students to have more of logical and critical ideas, she applied problem solving learning method using boxes and bullets to help students to map and arrange their ideas. As the group discussion ran, there were 5 out of 18 pairs who had less dynamic discussion. They let their partners to take decision on what should be written and agreed silently. Some of them looked frustrated because it seemed that their partners did not take their opinions into account for they were assumed rather incompetent. As for individual learning experience, it was noted that there were 6 out of 36 students who could not learn the material well. It was because two of them were late coming into the class and left behind without trying to ask the model or their friends about what they had missed; whereas four of them simply played around and gave little interest in learning. It led the students to have less deep insight about the material and barely practice their writing skill. It should have been better if the model approached these students directly and accompany them; hence they could work in group efficiently and be more serious in learning as the principle of classroom management suggested where instructors might maintain the momentum in the instruction by handling behavior problems using the small interference that would work (Slavin, 2009).

Based on the monitoring guide used and reflection See session, it was revealed that the models looked more composed and enjoyed their Do session without worrying the camera rolling as they thought they had done their best to conduct the Do session following suggestion given by the observers and the results of cycle I. The researcher noted that the writing classes in cycle II were more enjoyable than in cycle I. The majority of students were engaged in the learning processes and the number of those who were less active was decreased. The power point presentation used was quite useful with 
clear pictures and clues in the form of boxes and bullets so that the students who often dealt with getting to start writing could do it orderly. As the models gave more examples and practices as well as more challenging individual work than explanation, there were a few students giving questions to the model about the tips of using the English language to write a fine piece of writing. The models answered these questions using clues supplemented with their own experiences that were expected to make the students figure out the answers themselves. This was a keen way to teach adult learners as they could comprehend better if they were to critique their own work by generating a set of ideas in which one could look for sources and discover the answers (Slavin, 2009). Following this result, the models set up the preparation for cycle III.

\subsection{Cycle III}

The cycle III was done using the same steps as previous cycles; Plan, Do and See. After reflecting the results of cycle II, in Plan session, the models along with the observers confirmed the preparation for Do and See sessions. The models had designed lesson designs along with the lesson plans with the extension of the previous materials; the paragraph writing in class IIA was about describing place and the argumentative essay in class IIIA was about making citations (in-text reference and reference). The models also prepared analytical scoring rubric, teaching media, power point presentation with comprehensive examples, students' worksheets, and post-tests.

When implementing Do session, in the beginning the models did warm-up activity by asking the students to put their hands up one at a time for a few seconds. It was done to get the students' attention and not to let them sleepy. Afterward they did apprehension by giving humorous questions and showing interesting pictures. By having students ready to learn with such enjoyable situation, their expectation of the following activities would be raised. The models then applied problem-solving learning method collaborated with simultaneous roundtable in class IIA and with citation hut catching fire challenge in class IIIA. In addition, the models adjusted the lesson plans in accordance with the class situation. They had changed the group members from the previous cycle in order to give different group discussion experiences for each student. At the same time, they monitored each student and gave help when needed to ensure that the students got engaged in group discussion session. As the models kept walking around the class and giving clues whenever the students were stuck or seen distressed, all of them looked determined to create a writing product through group discussion. During 
discussion session, the students looked more confident in delivering their argumentation to support their own ideas as their group members did not judge them and helped them when they mispronounced some words, did code-switching frequently and made grammar mistakes. When sharing their group result in the front of the class, the students looked self-assured and motivated for the models gave recognition to each group that had the liveliest discussion and the most attention-grabbing writing. As this kind of motivation influenced their enthusiasm in learning followed by the eagerness to try to come up with the best group results, the discussion session had become more dynamic and fruitful. At the end of the instruction, before giving the individual post-tests, the models along with the students corrected their own worksheet and gave reinforcement; and concluded the materials learned afterward. Such learning atmosphere of an effective teaching which allowed them to connect information to other sources, think about it and use it outside of the classroom had led the meaningful learning experiences become apparent (Willingham, 2003). Hence, the $21^{\text {st }}$ century life skills that the students needed to possess such as being able to work collaboratively and communicatively as well as to think creatively and critically had been undergone. The students could work together and be critical to share opinions while discussing and using their creativity for the best group outcomes.

After Do session was completed, the models gave questionnaires for the students to remark their opinion about the teaching-learning processes for three cycles. They had shown positive responses toward the teaching-learning activities. It was stated that the students enjoyed the activities given. They were interested in learning the materials and learned many things for they were useful for their future. In addition they had fun during group discussion as the models underlined that they could speak whatever they wanted and be respected still. During group exhibition and recognition, they felt delighted as they could show their result and learn to be better. In addition, they gave recommendations for further instructions that the models could utilize other teaching strategies in teaching writing; thus the students might experience various learning processes.

During See session, the models and the observers reflected the implementation of Do session. As the session was opened by the moderator, the models looked excited to tell their teaching experiences of the previous Do session. They mentioned that they felt calm when managing the class activities, controlling the discussion and monitoring their students learning as they were used to having camera recording them and the observers watching them. They managed to control their voice volume so that the students could hear them well. At this point the researcher had a chance to share her experience when teaching by applying group discussion as the highlight. She told that she had 
had difficulties when trying to direct the students' learning noises. She felt it was fine as long as the noise was in English and remained in learning context. In addition, the models also affirmed that their anxiety of the observation result was reduced for they felt confident as the results of the students' post-tests were good and their reaction toward the activities was positive. In the point of view of the observers, it was revealed that the models performed their best in the last cycle and had managed the activities well. The noise of group discussion was lively and the discussion ran enthusiastically. Each student had learned the material well and helped each other to gain the same goal. The number of students who asked the models was increased along with quite critical questions given. The models had answered the questions indirectly using hints with description and examples.

Through this Lesson Study program, it was fundamentally found that educators could share their experiences, be open, evaluate each other performance and give suggestion for further instruction. It automatically enhanced the positive bond among colleagues. It was in line with Wang-Iverson and Yoshida (2005) who state that lesson study gives positive impacts to teachers and their colleagues. It helps to decrease teachers' isolation from their community; to observe teaching-learning processes and criticize teachers' teaching skills performances; to deepen the teachers' insight about the learning subject; to have knowledge exchanged about students' learning and thinking processes; and to enhance teachers' collaboration. Furthermore, as aforementioned findings, it was confirmed that teaching skills possessed by the writing lecturers of FTTE Unmas Denpasar were developed. The writing lecturers were capable of enhancing practical skill in designing lesson plans, making learning materials, teaching media, students' worksheets, scoring rubric and post-tests, motivating students, managing the classroom, communicating ideas, assessing learning outcomes and reviewing information. These attributes were comprised in teaching skills stated by Slavin (2009). Supporting these findings, Harmer (2007) mentions that to be good teachers, one must have teacher skills which feature ability to manage class, match tasks and groups, vary activities, decide and discuss learning outcomes or learning objectives; beside being warmth, humorist, and caring (Wayne and Youngs, 2003).

Considering the outcome of lesson study program which had directly impacted the instructors' teaching quality, the students' academic achievement were explicitly influenced. The same as what was concluded by Copriady (2013), lesson study could improve the educators' pedagogical competency in teaching which automatically induced their students' learning objectives. Through lesson study the educators were allowed to share experiences in teaching, give suggestion, and encourage each other so that for the 
upcoming processes they could organize better classroom instructions (Lenski, Caskey, Anfara, 2009).

\section{Conclusion and Suggestion}

Based on the findings and discussion explicated above, it could be concluded that educators' teaching skills were obliquely influenced by the implementation of lesson study based instruction in teaching writing toward the students of semester IIA and IIIA of ELSP FTTE Unmas Denpasar in academic year 2016/2017. The teaching skills developed featured practical ability in designing lesson plans, making learning materials, teaching media, students' worksheets, scoring rubric and post-tests, motivating students, managing the classroom, communicating ideas, assessing learning outcomes and reviewing information.

By learning these findings, the language instructors are suggested conduct the lesson study based instruction to develop their teaching skills performances which directly affect students' learning experiences to achieve the $21^{\text {st }}$ century life skills such as being communicative, collaborative, critical and creative. In addition, lesson study promotes the educators' personal growths in working together to finish particular tasks. They may share, encourage and evaluate each other as well as give and accept suggestion. Subsequently, their strong and weak points can be identified so that they can take pertinent decision to overlook their weaknesses and keep their strengths for the next instructions. Considering these facts, it is enabled to have instructors perform lesson study based instruction in any subject and level of education. Furthermore, lesson study can be prompted by amalgamating it with various teaching techniques/strategies/methods; instructors can select suitable one to use.

\section{References}

[1] Brown, H., D. 1994. Teaching by Principles: An Interactive Approach to Language Pedagogy. New Jersey: Prentice Hall Regents.

[2] Copriady, J. 2013. The Implementation of Lesson Study Programme for Developing Professionalism in Teaching Profession. Asian Social Science. Vol. 9. No. 12. Page 176-186.

[3] Hamalik, O. 2008. Proses Belajar Mengajar. Jakarta: Bumi Aksara.

[4] Harmer, J. How to Teach English. Essex: Pearson Education Limited. 
[5] Herrel, A., \& Jordan, M. 2004. Fifty Strategies for Teaching English Language Learners. Second Edition. New Jersey: Pearson.

[6] Hoover, K. 1966. Learning and Teaching in the Secondary School. Boston: Allyin and Bacon Inc.

[7] Lenski, S.,J., Caskey, M.,M., \& Anfara, V.,A. 2009. Using the Lesson Study Approach to Plan for Students' Learning. Curriculum and Instruction Faculty of Publications and Presentations. Portland State of University.

[8] Murata, A., \& Takahashi, A. 2002. Vehicle to connect theory, research, and practice: How teacher thinking changes in district-level lesson study in Japan.

[9] Myers, J. 2012. Lesson Study as a Means for Facilitating Preservice Teacher Reflectivity. International Journal for the Scholarship of Teaching and Learning. Vol.6. No.1. Page 1-22.

[10] Ryegard, A., Apelgren, K., \& Olsson, T. 2010. A Swedish Perspective on Pedagogical Competence. Scholarship on Teaching and Learning (SoTL) cited on 21 September 2017 https://www.chalmers.com.

[11] Sandi, W. 2010. Pengembangan Bahan Workshop Lesson Study serta Implementasi oleh Guru Matematika di Madrasah Ibtidaiyah Negeri 1 Pangkalpinang.

[12] Slavin. R., E. 2009. Educational Psychology: Theory and Practice. New Jersey: Pearson.

[13] Susilo, H. 2017. Lesson Study for Learning Community. Workshop LSLC FKIP Universitas Mahasaraswati Denpasar.

[14] Visi dan Misi Program Studi Pendidikan Bahasa Inggris FKIP Unmas Denpasar. 2010.

[15] Wayne, A., J., \& Youngs, P. 2003. Teacher Characteristics and Student Achievement Gains: A Review. Review of Educational Research. Vol. 73. No. 1. Page 89-122.

[16] Willingham, D. 2003. Students Remember what They Think about. American Educator. Vol. 27. No. 2. Page 37-41. 